Acute bleeding from metastatic tumour of the papilla Vateri is an extremely rare case. In this report the case of a woman who suffered from complications after a metastatic tumour of the papilla is described. Seventeen years following resection of the kidney due to clear cell carcinoma the patient was admitted to the clinic because of massive bleeding (Forrest IB) to the upper digestive tract in the form of sanguineous vomiting. The conducted diagnostics revealed a bleeding tumour of the papilla Vateri. Endoscopic treatment could not effectively stop the bleeding. A surgical procedure was performed by Whipple's method. A histopathological examination showed a metastatic clear cell tumour of the kidney. The patient was discharged from hospital on the $8^{\text {th }}$ day following her admission and was also referred for further oncological treatment. The discussion is based on other cases of rare bleeding from the digestive tract within tumours of the bile duct and papilla Vateri.

Key words: papilla Vateri, acute bleeding into upper gastrointestinal tract, metastasis tumor.

Contemp Oncol (Pozn) 2013; 17 (5): 470-472 DOI: $10.5114 /$ wo.2013.37226

\section{A case of upper gastrointestinal acute bleeding as a complication of renal carcinoma metastases to the papilla Vateri}

\author{
Jacek Śmigielski, Łukasz Piskorz, Marcin Wawrzycki, Sławomir Jabłoński, \\ Marian Brocki
}

Clinic of Thoracic Surgery, Oncological and General Surgery, Medical University, Lodz, Poland

\section{Introduction}

Bleeding into the digestive tract is a prevalent problem during surgical procedures. The most common cause, $90 \%$ of all bleeding cases, is gastric and/or duodenal ulcer. We rarely deal with sanguineous gastritis or duodenitis, Mallory-Weiss syndrome or oesophageal varices. We should not forget about the possibility of the presence of tumour [1,2]. A doctor should take into account one of the illnesses of the upper digestive tract after the first symptoms such as sanguineous vomiting or haemoptysis. The implementation of a panel of diagnostic examinations should be the right decision as the cause of bleeding is not always, e.g. gastric ulcer.

Papilla Vateri tumour belongs to tumours of the distal part of the bile duct. The most common symptom of papilla Vateri tumour is jaundice. It is a chronic process. Not always, however, must it be the first symptom of the illness. This illness might be masked by symptoms suggesting other problems in the digestive tract. One of the acute symptoms in the digestive tract is bleeding. An endoscopic examination conducted correctly usually allows one to make the proper diagnosis. Unfortunately, until today in $10 \%$ of cases bleeding cannot be stopped using this method [2]. In such cases surgical treatment is recommended. In the case described the patient had an urgent operation after an unsuccessful attempt of an endoscopic procedure. In the literature we could not find a description of a similar case of metastatic tumour of kidney to papilla, the first and only symptom of which was massive bleeding into the digestive tract.

\section{Case report}

A woman, 81 years old, was admitted to the Clinic of Thoracic Surgery, Oncological and General Surgery of the Medical University of Lodz in May 2009, because of massive bleeding into the digestive tract.

On the basis of history it was stated that the patient fainted at home the day before admission to the hospital. Fainting also repeated on the day of admission to the hospital. The patient was vomiting with blood and coagulum. During urgent endoscopy of the upper digestive tract there was observed a lot of fresh blood in the oesophagus, stomach and duodenum. The bleeding site was revealed in the duodenum, from a papilla Vateri tumour. Argon plasma coagulation was used to stop the bleeding, but without success. An attempt to clip the bleeding part of the papilla finished similarly. Because of unsuccessful attempts using an endoscope, the patient was qualified for urgent operation.

Other data from history are as follows: the patient had many concomitant illnesses, including diabetes type 2 and hypertension. Past operations: appendicectomy 60 years ago, cholecystectomy 30 years ago, left nephrectomy 17 years ago. 
In additional examinations during the admission to the hospital: blood morphology: erythrocytes 1750 000/ml, haemoglobin $4.8 \mathrm{~g} \%$, haematocrit $19.6 \%$, leukocytes 11 900/ml, urea $7.0 \mathrm{mmol} / \mathrm{l}$, creatinine 97.0 umol/l, alanine aminotransferase $14.0 \mathrm{IU} / \mathrm{l}$, aspartate aminotransferase $18.0 \mathrm{IU} / \mathrm{l}$, total bilirubin $23.1 \mathrm{\mu mol} / \mathrm{l}$, C-reactive protein $343.6 \mathrm{mg} / \mathrm{l}$, sodium $140 \mathrm{mEq} / \mathrm{l}$, potassium $3.9 \mathrm{mEq} / \mathrm{l}$, calcium $2.00 \mathrm{mg} \%$, diastase $33 \mathrm{IU} / \mathrm{l}, \boldsymbol{\gamma}$-glutamyl-transpeptidase $55 \mathrm{IU} / \mathrm{l}$, total protein $54.9 \mathrm{~g} / \mathrm{l}$, albumin $25.5 \%$.

In anaesthesiological opinion the patient was classified as ASA 3. The patient had pancreatoduodenectomy with local lymphadenectomy using Whipple's method. Postoperative complications with high fluctuation of glycaemia and constant lack of blood parameters. The patient had $3100 \mathrm{ml}$ of red blood cells and $2400 \mathrm{ml}$ of fresh frozen plasma transfused during her stay in the hospital. On the $6^{\text {th }}$ day after the operation morphological parameters were stabilised as well as the norm of protein quantity in the organism. During hospitalization a CT scan of the abdomen and X-ray of the thorax were conducted in order to search for other possible metastatic sites. Other changes were not observed. The patient was discharged from the hospital on the $8^{\text {th }}$ day after the operation and was referred for further gastric and oncological treatments as well as other additional treatments.

In histopathological examination no. 5359-5370/2009 from 27.05.2009 - from a resected preparation of the papilla Vateri we had a result: carcinoma clarocellularae $\mathrm{G} 2$. This change was cut out completely. T2NOMO.

\section{Discussion}

The described case of the patient with bleeding metastatic tumour of renal clear cell carcinoma to the papilla Vateri is a very rare complication of a tumour in this area. The first and the main symptom of this illness in the form of bleeding was life threatening for the patient. Nowadays, widespread access to endoscopic techniques allows us to stop bleeding successfully. Thanks to the techniques used today such as clips, obliteration of vessels, diathermy or laser, it is possible to stop bleeding in up to $90 \%$ of cases using an endoscope [2-4]. In the case described, endoscopic treatment could not stop the bleeding. After the second attempt with the endoscope this technique was abandoned and it was decided to perform a surgical intervention, taking into account the general poor condition of the patient and low blood parameters.

The case of our patient is quite interesting. It results from several factors:

- the patient was admitted to the hospital with features of acute bleeding to the digestive tract;

- an endoscopic attempt to stop the bleeding was used by choice (after the second, unsuccessful attempt, an endoscopist together with a surgeon decided to stop other endoscopic attempts and start the operation urgently);

- the right decision of the surgeon to perform Whipple's procedure, which later confirmed the histopathological diagnosis (simultaneous aspect to stop bleeding and complete removal of tumoural changes).

The gland cancers are localised most frequently in the papilla Vateri or in its vicinity. They comprise over $90 \%$ of all tumours in this area. The second group of tumours, in terms of frequency of occurrence, is neuroendocrine tumours (NET) [5]. However, metastatic tumours occur in this area very rarely. Rego and co-authors described metastasis of lung cancer to the papilla Vateri [6]. The symptoms of tumours might vary. It depends on their histological forms. In world publications there are single cases of other forms of papillae tumours described, such as GIST, desmoid, carcinoid, adenomyoma, leiomyoma, plasmocytoma or somatostatinoma [5-9]. Bleeding from such papillae is usually quite massive and the condition of patients changes dynamically. Spontaneous bleeding from the duodenum that requires performance of pancreatectomy is described by Standop and co-authors [10]. The procedure is similar and equally urgent. A team working efficiently - an endoscopist, an anaesthesiologist, and a surgeon - is able to influence the prognosis. High blood loss might require intensive cardiac and anaesthesiological actions in order to maintain organism efficiency. The surgeon who is to choose the type of procedure might decide (as in this case) on pancreatoduodenectomy, stopping bleeding immediately and removing the tumour at the same time. In many cases, we deal with incidental tumours, detected randomly during routine mass screening or detected secondarily as a result of different symptoms complicating this kind of tumours: jaundice or as in this case massive bleeding into the digestive tract. As in the case of jaundice we can postpone a procedure to extend diagnostics and perform, e.g. ERCP and take material for histological examination, but in the case of complications such as bleeding, there is no time for such a procedure $[1,4]$. The patient described had endoscopic treatment, but because of the intensification of symptoms it was unsuccessful. She was operated on urgently. The small size of the tumour and convenient anatomical conditions were favourable to perform pancreatoduodenectomy. The correctness of such a decision was confirmed only after histopathological diagnosis - metastasis from renal clear cell carcinoma.

In the case described, there is also another important fact not to be overlooked: a precisely completed history (in many cases collected from the family because of the poor condition of the patient as well as reduced morphotic blood values) - a subjective examination from which we found out about the presence of renal carcinoma and the cause of nephrectomy 17 years ago. During the urgent operation this fact was very important and influenced the decision of the surgeon on the type of procedure. The situation in which the surgeon started a procedure should be analysed: a patient with massive bleeding, erythrocytes 1750 000/ml, haemoglobin 4.8 g\%, haematocrit 19.6\% - the least invasive procedure was advised, but the knowledge from history gave a possibility to perform it correctly. After stopping bleeding and stabilization of the patient, the treatment was performed in the sense of radical oncological one and not only as haemostatic.

The authors declare no conflict of interests. 


\section{References}

1. Octavio de Toledo JM, Gómez Lorenzo F, Santiago MP et al. Upper digestive hemorrhage caused by ulcerated periampullary leiomyoma. Rev Esp Enferm Dig 1991; 79: 156-9.

2. Hara M, Łaska G, Pasek K. Plasmocytoma - A rare couse of upper gastrointestinal bleeding. Case report. Pol Przegl Chir 2010; 82: 311-316.

3. Onal IK, Kurt M, Akdogan M, Kalkan IH, Kiremitci S, Odemis B, Oguz D, Sasmaz N. A rare cause of upper gastrointestinal bleeding: stromal tumor of duodenum masquerading as papilla vateri. Am J Gastroenterol 2009; 104: 535.

4. Acuna-Soto R, Braun-Roth G. Bleeding ulcer in the common bile duct due to fasciola hepatica. Am J Gastroenterol 1987; 82: 560-2.

5. Pitt SC, Pitt HA, Baker MS, et al. Small pancreatic and periampullary neuroendocrine tumors: resect or enucleate? J Gastrointest Surg 2009; 13: 1692-8

6. Rego RF, Atiq M, Velchala N, Nevin D, McElreath DP, McKnight WD, Aduli F. Ampullary metastasis from breast cancer: an unusual finding. Endoscopy 2009; 41 Suppl 2: 278-9.

7. Wellmann K, Gohla G, Wenk H. Malignant gastrointestinal stromal tumor (GIST) of the papilla vateri. A rare tumor entity. Chirurg 2004; 75: 196-9.

8. Bedirli A, Patiroglu TE, Sozuer EM, Sakrak O. Periampullary adenomyoma: report of two cases. Surg Today 2002; 32: 1016-8.

9. Wittekind C, Tannapfel A. Adenoma of the papilla and ampullapremalignant lesions? Langenbecks Arch Surg 2001; 386: 172-5.

10. Standop J, Glowka T, Schmitz V, Schaefer N, Hirner A, Kalff JC. Emergency Kausch-Whipple procedure: indications and experiences. Pancreas 2010; 39: 156-9.

\section{Address for correspondence}

Jacek Śmigielski Md, PhD

Department of Thoracic, General and Oncologic Surgery

Medical University of Lodz

Żeromskiego 113

90-547 Lodz, Poland

Submitted: $\quad 22.02 .2011$

Accepted: $\quad$ 10.05.2012 